\title{
The Semantic Role of Core Argument on Batak Toba
}

\section{Language}

\author{
Yayuk Hayulina Manurung ${ }^{\mathrm{a}}$, Mulyadi ${ }^{\mathrm{b}}$ \\ a yayuk.hayulina.manurung@students.usu.ac.id \\ ${ }^{\text {a }}$ University of Sumatera Utara, J1. Dr. T. Mansur No. 9 Padang Bulan, Medan 20222, Indonesia \\ ${ }^{\mathrm{b}}$ University of Sumatera Utara, J1. Dr. T. Mansur No. 9 Padang Bulan, Medan 20222, Indonesia
}

\begin{abstract}
This study examines the semantic role of the Toba Batak language's core arguments. The theory used is the macro role. This study uses a qualitative method. The data sources are in the form of spoken text and written text in Batak Toba language. The results showed that the semantic role of the core arguments in the Batak Toba language consisted of macro roles and thematic roles. macro roles consist of actor and undergoer, while thematic roles consist of agent, experiencer, effector, recipient, theme, source, and patient.
\end{abstract}

Keywords: toba; role; semantic; argument; core

The semantic role is the role contained in the predicate argument, which offers both the perpetrator and the sufferer to explain semantic relationships between the predicate and the argument. Actors are arguments that express participants who shape, influence, or control a situation is declared a predicate, while the sufferer is an expressing argument participant who do not form, do not initiate, do not control the situation, but is influenced by the action of the verb. Doers and sufferers are roles general in which special roles are involved such as agent, patient, influencers, locatives, and themes. These two roles won't change though the syntactic manifestations are different (Foley and Van Valin, 1998).

Batak Toba language has its own uniqueness or uniqueness like that owned by other regional languages. The uniqueness or uniqueness of this language attract the attention of linguists. This can be seen in the results of the studies of several expert languages that have conducted research on Toba Batak language, namely in aspects grammatical, phonological, morphological and syntactic such as the semantic role of verbs on Toba Batak language (Butar-butar,J,2008), Toba Batak language grammar relations: the threat of typology (Siagian, BA, 2014) namely Grammatical roles and relations of Batak Toba Language: typology study (Simanjutak, T.A \& Mulyadi,2019), batak Toba language morphological system: a generative transformational study (Ambarita, E, 2019), Adjectival affixations in Toba Batak language: a descriptive analysis of adjectives (Ambarita, E 2018), Nominal Affixation between English and Toba Batak language (Manulang, EB, 2012), The phonological process of Batak Toba (Lubis, J. 2013), Adverbial Derivation In Toba Batak Language: A Generative Transformational Study (Ambarita, E. 2018), Incorporation with verb deletion in Toba Bataknese Language Simanjuntak F \& Mulyadi. 2019) and others.

This research is conducted in relation to syntactic studies. In this research, the writer will take the semantic role of verbal clause argument of Toba Batak Language. Role is relationship each argument and predictor. Semantic, related or related to meaning. To know the meaning of a word in a clause, mentally as much as possible someone is able to distinguish meaning and meaning. Meaning is meaning contained in the word or sentence, while the meaning is the intention speaker or writer. The meaning in this context is the meaning contained in the role assigned to an argument. An argument is a number of elements or participants 
who are bound by verbs. Based on the simple explanation above, then It can be concluded that the semantic role is the role given to argument by predicate, whereas the semantic role of argument is that role given to a number of arguments by predicate or verb in a clause.

\section{Macro-Roles Theory}

Van Valin (2005: 60) mentions two semantic roles, namely actor and experience (undergoer). Determination of the role of the actors in each behaviour that is displayed has a level. High difficulty in interpreting because the meaning of an actor's behaviour is intuitive. Due to its nature, it is possible that a core argument has several different semantic roles. It is stated that the actor (actor) is an argument that takes action form (perform), influence, instigate (instigate), or control a situation stated by the predicate. On the other hand, the undergoer is an argument expressing participants who do not form, do not control the situation, but affected by the action expressed in the verb. These two roles are permanent even though their syntactic forms are different. The experience is called the transitive predicate argument and the intransitive predicate argument. This matter show that they are different from syntactic relations such as subject and object or the role of the case (case role) such as agent and patient. As for the realization in an argument. The verb will have a variety of different roles according to the semantic characteristics of the predicate (Van Valin, 2005: 60). The two roles described above are general roles. In the general role there are also special roles. Some of them are agents, influencing, locative, theme, and patient. Because of the division of roles that way, Foley and Van Valin (1994: 59) creates thematic hierarchies to facilitate the interpretation of various roles semantic derivatives and explains the semantic roles that may be involved in mapping (mapping) the arguments. Van Valin and Lapola (1999) propose some general principles for determining macro role, namely the number and nature. The number of macro verbal roles is less or equal to the number argument on its logical structure. If a verb has two or more arguments to the structure logically, the verb has two macro roles. If a verb has one argument or rather in its logical structure, the verb has a macro role.

Van Valin Jr. (2005: 60) states that there are two semantic roles, namely the actor and the undergoer. Actors are arguments that perform actions, effects, instigate, or control situations stated by the predicate. Meanwhile, experience is an argument that expresses participants who do not form, do not control the situation, but are influenced by the actions expressed in the predicate.

\section{Method}

This study used a qualitative approach that aimed to describe and explain the role of semantic argument on Batak Toba language. Data were analysed through exposure to reality naturally and as it is. Data was supported by deductive and inductive approaches, and was collected in natural conditions using field linguistic research methods and library methods (documentary). Field linguistic research that involved direct participation of language speakers was carried out by observation attentively from the informants. The observation method includes the tapping technique, the skilful engaging listening technique, the skilful engaging free listening technique, the recording technique, and the note-taking technique (Sudaryanto 1993). Another method used is the library method (documentary) to support oral data by collecting data in the form of a literary text corpus by taking a number of data in the form of clauses / sentences of the Toba Batak language from the data source. In this study, researchers used primary data (oral text) and secondary data (written text). Primer data in this study were data obtained by researchers directly from native speakers of Toba's native language which was then recorded by researchers. 


\section{Result And Discussion}

As it is stated by Van Valin Jr. (2005: 60) related the two semantic roles namely the actor and undergoer, the actors themselves refer to the arguments that perform actions, effects, instigate, or control situations stated by the predicate. Meanwhile, experience is an argument that expresses participants who do not form, do not control the situation, but are influenced by the actions expressed in the predicate. Here is the description the role of semantic argument on Batak Toba language:

\section{Agent}

Agent is a role filled by noun phrases or nouns (Van Valin 2005: 23). In the active form, the agent is the subject and the patient is the direct object, whereas in passive form, the patient is the subject and the agent is not the subject. The agent is the perpetrator who takes action or action in accordance with what he wants. In other words, agent are instigators who perform actions or events on purpose and with purpose certain (Iswara 2015: 388)

Look at the following data:

- $\quad$ lao mandurung dengke ibana

Go to catch fish he

He goes to catch the fish

- mangalompa indahan ina di jabu

Cooks the rice mom at home

Mom cooks the rice at home

The two examples above show that there is a certain role in each element sentences in Batak Toba. The argument for ibana 'he' and ina 'mother' (46) plays the role of the perpetrator because he is the perpetrator of the predicate lao mandurung 'to go and catch' and mangalompa 'to cook'.

\section{Effector}

The argument that serves as the cause (effector) is generally the actor of the action or events that are carried out, whether intentionally or unintentionally (Iswara 2015: 389). According to Trask (1996: 88), effector is a noun phrase that has principles like an actor as it is seen the example below:

- udan habahaba manegai suansuanan di kobun

The thunderstorms destroy crops in the garden

Data in clauses is data in which there is a role for arguments cause. manegai "destroy" is the predicate in the clause above and which acts as an effector or cause is udan habahaba 'rainstorm'. It is called acts as an effector because the actor takes certain actions that have an impact on the object.

\section{Experiencer}

Experience is an argument that states an experience and an event psychological, both sensation, emotion and cognitive (Parera 1993: 125). Van Vallin and Folley (1984: 29) explain that experience is a role argument that does not perform, organizing, playing, initiating, initiating or controlling circumstances. While therefore, Trask (1996: 97) defines the role of the experience as a semantic role comes from a nominal phrase which denotes an animate object which is feel or experience something. For example: 
- Marsahit si Tigor

Is sick Tigor

Tigor is sick

- iburu ibana nabodari

Get jealuos She Yesterday

She gets jealous yesterday

In the data above, the argument of marsahit 'si Tigor' and iburu ibada nabodari have the role of experiencer as a nominal, animate phrase that feels or experiences something

\section{Recipient}

Van Vallin (2005: 24) explains that the recipient can be seen syntactically as an indirect object as in Chris gave the notebook to Dana and as the subject on Sandy's clause received the message from Bill. In the clause Chris gave the notebook to the funds, which are the recipients are those which are indirect objects. Meanwhile, on Sandy's clause received the message from Bill, the recipients were Sandy and serves as a subject. As is the case in English, the Batak Toba language is also available clause indicating the recipient.

For example:

manjalo hepeng angkang sian ama

Receives the money brother from dad

The brother receives a work summons today

\section{Source}

According to Trask (1995: 255), the source is the semantic role expressed by the noun phrase which expresses the starting point of motion abstractly or concretely. Iswara (2010) explains that if there is a displacement, the initial position is the source / origin, the object is the theme and the final position is the receiver. For example, in the sentence 'Daddy gives a candy to Vares'. The role of the father's argument can be both as an agent and as a source. In the sentence 'Mother buys a chicken from uncle', the mother's role can be as an agent at the same time the recipient

For example:

- ompung doli mangalehon damang dua ihur horbo

Grandad gives dad two buffaloes

The data above is a dual transitive clause. Grandad 'ompung' in the above clause semantically act as both the actor and the source. The phrase two ihur horbo '2 buffaloes' is NP that has shifted position, while the damang 'father' is the target or recipient.

\section{Theme}

Theme is the role of an argument placed in a place or an argument who experienced a location shift. Apart from that, the role of the theme also indicates the entity which is owned or who has undergone a change of ownership (Van Vallin 2005: 24). The role of the theme has in common with the patient's role because it is subjected to the activity or action of the verb carried out by an agent. What 
distinguishes it is the role of the theme experiencing displacement or movements caused by the verb (Iswara 2015: 388). Look at the following data:

- Manuhor tano Tigor sian Panjaitan

Bought the land Tigor from Panjaitan

Tigor bought the land from Panjaitan

The manuhor verb in the above clause has two core arguments, namely Tigor 'old man' and tano 'land'. tano 'land' served as the theme. The role of the theme tano 'land' in the data above experiences a movement caused by the verb, namely the verb manuhor 'buy'. According to Van Valin (2005: 24), a role is said to play a theme if it has verbs to save, put, give, send, and buy.

\section{Patient}

The patient is an argument that is both animate and lifeless that resides in a state or experiencing state changes caused by verbs. Patients usually characterized by the appearance of the verbs kill, hit, break, crush, wash, and devastating (Van Vallin 2005: 24). Look at the following data:

- ibana manduda donganna

He smashed his friend

In the data above, the companion element 'donganna' is an argument that acts as a patient and is bound by the manduda verb 'to grow'. Based on the description above, it can be concluded that the semantic role of the Toba Batak language is the actor, the cause, the experience, the source, the theme, and the patient.

From the description above, it is clearly seen that principally the semantic role of core on Batak Toba language has no differences comparing with English as it is described by (Foley and Van Valin, 1998). Batak Toba language has two semantic roles namely the actor and undergoer, the actors themselves refer to the arguments that perform actions, effects, instigate, or control situations stated by the predicate. Meanwhile, experience is an argument that expresses participants who do not form, do not control the situation, but are influenced by the actions expressed in the predicate.

\section{Conclusion}

The semantic role of core argument on Batak Toba language is divided into two parts, namely the macro role and the thematic role. The macro role consists of Actor and Undergoer, while the thematic role consists of agent, effector, experiencer, recipient, source, theme, and patient.

\section{Acknowledgements}

I am deeply indebted to my lecturer of linguistic typology, Dr. Mulyadi. Secretary of Department of linguistics doctoral program University of Sumatera Utara, for his guidance.

\section{References}

Ambarita, Esron. 2019. Toba Batak Language Morphological System: A Generative Transformational Study. Research Gate

Ambarita, Esron. 2018Adjectival affixations in Toba Batak language: a descriptive analysis of adjectives, Conference of ELT,

Linguistics, Literature and Translation (ICELLT 5th) Graduate School of NHU, North Sumatra Indonesia

Ambarita, Esron. 2018. Adverbial Derivation In Toba Batak Language: A Generative Transformational Study 
https://jurnal.uisu.ac.id/index.php/languageliteracy/article/view/689

Artawa, I Kt. 2000. —Alternasi Diatesis pada Beberapa Bahasa Nusantarall dalam Kajian Serba Linguistik untuk Anton Moeliono Pereksa Bahasa (editor: Purwo, B. K.). Jakarta: Universitas Katolik Indonesia Atma Jaya dan PT. BPK Gunung Mulia.

Comrie, Bernard. 1989. Language Universals and Linguisitc Typology. Oxford: Basil Blackwell Publisher Limited

Iswari, A. A. (2015). Fungsi sintaksis dan peran semantik argumen frasa verba bahasa Bali. Retorika, Jurnal Ilmu Bahasa, Vol. 1(2),

Oktober 2015, 388-402.

Jufrizal. 2005. —Konstruksi Zero Klausa Bahasa Minangkabau: Pasif, Pentopikalan, atau Ergatif? (makalah disajikan pada PLU-4 di Universitas Sumatera Utara; 13 - 14 September 2005). Medan: Universitas Sumatera Utara Vol-4, Issue-6, Nov - Dec 2019 https://dx.doi.org/10.22161/ijels.46.53 ISSN: 2456-76

J. Lubis, "The Phonological Process of Batak Toba Language," Lantern (Journal on English Language, Culture and Literature), vol. 2, no. 3, pp. 24-40, Sep. 2013. [Online].

Manullang, Elisa B (2012). Nominal Affixation Between English And Batak Toba Language, https://jurnal.unimed.ac.id/2012/index.php/bahas/article/view/5651/5066

Mulyadi. 1998. Struktur Semantis Verba Bahasa Indonesia. (Tesis). Denpasar: Program Magister Linguistik Universitas Udayana.

Siagian, Beslina Afriani, 2014. Relasi Gramatikal Bahsa Batak Toba: Ancaman Tipologi (Resipitory USU) Medan;

Simanjuntak Faido \& Mulyadi. 2019. Incorporation with verb deletion in Toba Bataknese Language. International Journal of English, Literature and Social Sciences (IJELS) ISSN:2456-7620

Simanjutak. Tarida Alvina \& Mulyadi. 2019. Grammatical Roles and Relations of Batak Toba Language: International Journal of English Literature and Social Sciences (IJELS) Vol 4 https://dx.doi.org/10.22161/ijels.4.3.42 ISSN: 2456-7620

Sudaryanto, 1993. Metode dan Aneka Teknik Analisis Bahasa. Yogyakarta: Duta Wacana University Press. Sudipa, I Nengah. 2005. Verba Bahasa Bali Sebuah Kajian Peran Semantik. Dalam Bahasa Sastra dan Budaya dalam Untaian

Trask, R. I. (1996). A Dictionary of Grammatical Terms in Linguistics. England: Brighton 